\title{
DETERMINATION OF Cd, Cu, Fe, Mn AND Pb IN EUROPEAN CARP (CYPRINUS CARPIO CARPIO)
}

\author{
Stancheva M., L. Makedonski, K. Peycheva \\ Department of Chemistry, Medical University - Varna \\ Reviewed by: assoc. prof. N. Negrev
}

\begin{abstract}
The concentrations of five elements ( $\mathrm{Cd}, \mathrm{Cu}, \mathrm{Fe}, \mathrm{Mn}$, and $\mathrm{Pb}$ ) were determined in the muscle, liver, gills, bones and skin of cultured carp (Cyprinus carpio carpio) caught at Tzonevo Dam in region Varna, Bulgaria. The samples analyzed for $\mathrm{Cd}, \mathrm{Cu}, \mathrm{Fe}, \mathrm{Mn}$ and $\mathrm{Pb}$ by Atomic Absorption Spectrometer. The highest levels of $\mathrm{Pb}$, Mn and Cd were found in the skin of the fish specie $(5.26 \mathrm{mg} / \mathrm{kg} \mathrm{w.w.,} 8.74 \mathrm{mg} / \mathrm{kg} \mathrm{w.w.} \mathrm{and} 0.34 \mathrm{mg} / \mathrm{kg} \mathrm{w.w.,} \mathrm{re-}$ spectively) while $\mathrm{Cu}$ and $\mathrm{Fe}$ had been accumulated predominantly in the gills $(2.68 \mathrm{mg} / \mathrm{kg} \mathrm{w} . \mathrm{w}$. and 55.54 $\mathrm{mg} / \mathrm{kg} \mathrm{w.w.} \mathrm{respectively).} \mathrm{Among} \mathrm{the} \mathrm{metals} \mathrm{analyzed} \mathrm{Fe} \mathrm{was} \mathrm{the} \mathrm{most} \mathrm{abundant} \mathrm{in} \mathrm{the} \mathrm{different} \mathrm{tissues,} \mathrm{while}$ $\mathrm{Cd}$ and $\mathrm{Cu}$ where the least abundant. The results obtained in this study were compared with those reported in other studies. The concentration of these five elements in the European carp samples found in the literature showed a similar tendency except for $\mathrm{Pb}$. Metal concentration in the edible part of the examined fish (muscle) was in the safety permissible levels for human consumption set by various health organizations.
\end{abstract}

Key words: Heavy metals, cultured carp, liver, gills, AAS, Bulgaria

\section{INTRODUCTION}

Fish is the final chain of aquatic food web and an important food source for humans. Water pollution leads to contamination of fish species with toxic metals, from many sources, e.g. industrial and domestic waste water, natural runoff and contributory rivers $(16,14)$. In the water basin, pollutants are potentially accumulated in organisms and sediments, and subsequently transferred to man through the food chain (17). For this reason, determination of chemical quality of aquatic organisms, particularly the contents of heavy metals in fish is extremely important for human health (5).

A well known fact is that fish muscle is not an active tissue in accumulation of heavy metals (18). On the contrary liver is a good monitor of water pollution with metals since their concentrations are proportional to those present in environment. Dam lake ecosystems are vulnerable to heavy metal pollution. Tzonevo Dam is situated in the Valley of Luda Kamchia River and ranks third in size in region Varna, Bulgaria. It is biodiversity is of importance for the local residents. Recently, agricultural and industrial developments as well as increase in population have substantially increased the contamination of Tzonevo dam.

Address for correspondence:

L. Makedonski, Dept. of Chemistry, Faculty of Pharmacy, Medical University Prof. Dr. Paraskev Stoyanov, 55 Marin Drinov St., 9002, Varna, BULGARIA

Bulgaria phone +359 52677074

e-mail: lubomir60@yahoo.com
The aim of this study is to investigate the distribution of selected metals $(\mathrm{Cd}, \mathrm{Cu}, \mathrm{Fe}, \mathrm{Mn}$ and $\mathrm{Pb})$ in different tissues (muscle, skin, gills, liver and bones) of the cultured carp (Cyprinus carpio carpio) collected from Tzonevo Dam by using atomic absorption spectrophotometer (AAS).

\section{MATERIAL AND METHODS}

\section{Biology and ecology of the fish sample}

Cultured carp dwells in middle and lower reaches of rivers and lakes and shallow confined waters and can survive cold winter periods. Carp are omnivorous, with a high tendency towards the consumption of benthic organisms. Zooplankton consumption is dominant in fish ponds where the stocking density is high. Additionally, the carp consumes the stalks, leaves and seeds of aquatic and terrestrial plants, decayed aquatic plants, etc.

\section{Sampling collection}

Samples of the fishes were acquired from three locations along Tzonevo Dam. All the fish species were sampled in July 2009. Total length and weight of the samples (total number 9) brought to laboratory on ice after collections were measured to the nearest millimeter and gram before dissection. The biometric data of the fish sample are as follows (mean $\pm \mathrm{SD}$ ): weight $1662.0 \pm 43.0 \mathrm{~g}$; length $45.5 \pm 8.0 \mathrm{~cm}$. Special care was taken to prevent metal contamination of the samples by the laboratory equipment. After biometric measurements, the fishes were immediately dissected, washed 
with distilled water, weighted, packed in polyethylene bags and stored at frozen at $-18{ }^{\circ} \mathrm{C}$ until chemical analysis.

Approximately $1 \mathrm{~g}$ sample of muscle, gills, skin and bones and entire liver were dissected, washed with distilled water, weight, packed in polyethylene bags and stored at $-18{ }^{\circ} \mathrm{C}$ until chemical analysis.

\section{Analytical procedure}

All reagents were of analytical reagent grade unless otherwise stated. Double deionised water (Milli-Q Millipore $18.2 \mathrm{M} \Omega \mathrm{cm}^{-1}$ resistively) was used for all dilutions. $\mathrm{HNO}_{3}$ was of suprapur quality (Merck, Darmstadt, Germany). The elemental standard solutions used for calibration were produced by diluting a stock solution of $1000 \mathrm{mg} / \mathrm{l}$ of the given element supplied by Sigma Chem., Co., USA

All tissues samples were transferred to a $100 \mathrm{~mL}$ Teflon beaker. Thereafter, $10 \mathrm{~mL}$ ultrapure concentrated nitric acid was added slowly to the sample. The Teflon beaker was covered with a watch glass, and heated at $200{ }^{\circ} \mathrm{C}$ on a hot plate for $3 \mathrm{~h}$, until the solution evaporate slowly to near dryness. Two milliliters of $1 \mathrm{~N} \mathrm{HNO}_{3}$ was added to the residue and the solution was evaporated again on the hot plate. By repeating the additional digestion twice, all organic materials in each sample were completely digested. After cooling, $2.5 \mathrm{~mL}$ of $1 \mathrm{~N} \mathrm{HNO}_{3}$ was added to digested residue and was transferred to $25 \mathrm{~mL}$ volumetric flasks, then diluted to level with deionized water. Before analysis, the samples were filtered through a $0.45 \mathrm{\eta m}$ nitrocellulose membrane filter (1). All samples were analyzed three times for $\mathrm{Cd}, \mathrm{Cu}$, $\mathrm{Fe}, \mathrm{Mn}$ and $\mathrm{Pb}$ by Atomic Absorption Spectrometer (Varian Model Spectrometer AA-240). Deuterium background corrector was used. Copper, manganese, cadmium, iron and lead were determined in air-acetylene flame. The operating parameters for working elements were set as recommended by manufacture given in Table 1 .

Table 1. Instrumental analytical conditions of investigated elements

\begin{tabular}{|l|c|c|c|c|c||}
\hline \hline $\begin{array}{l}\text { Working } \\
\text { conditions }\end{array}$ & $\mathbf{M n}$ & $\mathbf{C u}$ & $\mathbf{C d}$ & $\mathbf{F e}$ & $\mathbf{P b}$ \\
\hline Wavelength (nm) & 279.5 & 324.8 & 228.8 & 248.3 & $\begin{array}{c}283.3 \\
\text { and } \\
217.0\end{array}$ \\
\hline Slit width (nm) & 0.2 & 0.5 & 0.5 & 0.2 & 1.0 \\
\hline Lamp current (mA) & 5 & 4 & 4 & & 10 \\
\hline Ar flow (m1/min) & 250 & 250 & 250 & 250 & 250 \\
\hline Acetylene/air ratio & $3.5 / 1.5$ & $3.5 / 1.5$ & $3.5 / 1.5$ & $3.5 / 1.5$ & $3.5 / 1.5$ \\
\hline
\end{tabular}

The analytical measurements were based on peak height. Standard solutions were prepared from stock solutions (Merck, multi element standard).

\section{RESULTS AND DISCUSSION}

The results of the analyses for trace metals in european carp in muscle, skin, gills, liver and bond tissues are shown in Table 2 expresses as $\mathrm{mg} / \mathrm{kg}$ wet weight ( $\mathrm{mg} / \mathrm{kg}$ w.w.).

Table 2. The mean heavy metal concentration $(\mathrm{mg} / \mathrm{kg}$ wet weight $\pm S D$ ) in the different tissues of cultured carp (Cyprinus carpio)

\begin{tabular}{||l|c|c|c|c|c||}
\hline \hline & $\mathbf{C d}$ & $\mathbf{C u}$ & $\mathbf{P b}$ & $\mathbf{M n}$ & $\mathbf{F e}$ \\
\hline Muscle & $0.09 \pm 0.01$ & $1.03 \pm 0.1$ & $0.60 \pm 0.06$ & $0.52 \pm 0.05$ & $16.41 \pm 1.6$ \\
\hline Skin & $0.34 \pm 0.03$ & $1.15 \pm 0.11$ & $5.2 \pm 0.53$ & $8.74 \pm 0.8$ & $10.63 \pm 1.0$ \\
\hline Gills & $0.25 \pm 0.02$ & $2.68 \pm 0.25$ & $2.53 \pm 0.25$ & $4.83 \pm 0.5$ & $55.54 \pm 5.5$ \\
\hline Liver & $<0.01$ & $0.74 \pm 0.07$ & $0.45 \pm 0.05$ & $0.05 \pm 0.01$ & $17.18 \pm 1.7$ \\
\hline Bones & $0.19 \pm 0.02$ & $0.72 \pm 0.07$ & $4.1 \pm 0.41$ & $2.67 \pm 0.3$ & $9.02 \pm 0.90$ \\
\hline \hline
\end{tabular}

Cadmium is accumulated in human tissues. It is known that most human exposure to $\mathrm{Cd}$ is from food and is a serious contaminant, a highly toxic element, which is transported in the air. The lowest and highest cadmium levels in studied sample were $0.09 \mathrm{mg} / \mathrm{kg}$ w.w. for muscle tissues and 0.34 $\mathrm{mg} / \mathrm{kg} \mathrm{w} . \mathrm{w}$. for skin, respectively. The concentration for $\mathrm{Cd}$ in liver was below the limit of detection for this element. Unfortunately maximum permitted level of $\mathrm{Cd}$ is set only for seafood (especially for muscle tissues) as $0.05 \mathrm{mg} / \mathrm{kg}$ fresh wet weight according to European Union (6) and Bulgarian Food Authorities (3). The World Health Organization (WHO) sets permissibly tolerable weekly intake (PTWI) for $\mathrm{Cd}$ as $0.007 \mathrm{mg} / \mathrm{kg}$ body weight (7). Altindağ and Yiğit (2005) reported Cd values as $0.543 \mu \mathrm{g} / \mathrm{g}$ for muscle tissues and 0.658 for gill of Cyprinus carpio from Lake Beyşehir, Turkey (2). Cd values varies from $0.23 \mu \mathrm{g} / \mathrm{g}$ to $0.54 \mu \mathrm{g} / \mathrm{g}$ in muscle of Cyprinus carpio from Yeşilirmak

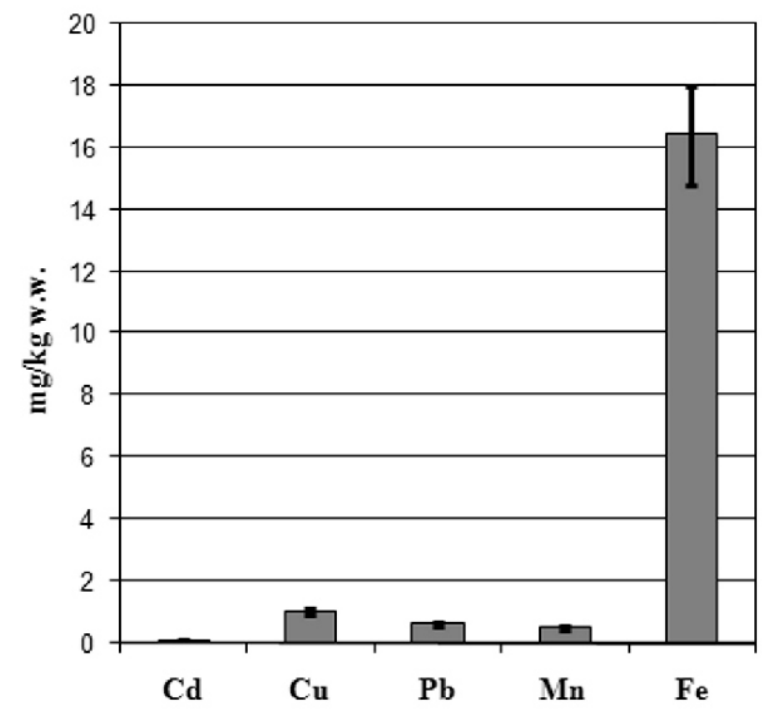

Fig.1. The mean heavy metal concentration in muscle of cultured carp (Cyprinus carpio) 
River in Tokat, Turkey (10); from $0.03 \mu \mathrm{g}$ metal/g dry weight to $0.11 \mu \mathrm{g}$ metal/g dry weight for muscle tissues and $0.02 \mu \mathrm{g} \mathrm{metal} / \mathrm{g}$ dry weight to $0.35 \mu \mathrm{g}$ metal/g dry weight for liver tissues of three economically important fish species captured from the Tuzla lagoon (5). Our values are within the data stated in the literature.

As copper is essential part of several enzymes and for the synthesis of hemoglobin, most organisms have evolved mechanisms to regulate concentrations of this metal in their tissues in the presence of variable concentrations in the ambient water, sediments and food (19). The minimum and maximum copper concentration in this study were found in bones $(0.72 \mathrm{mg} / \mathrm{kg}$ w.w.) and gills $(2.68 \mathrm{mg} / \mathrm{kg}$ w.w.), respectively. There are no guidelines on acceptable levels of $\mathrm{Cu}$ in the edible parts (muscle) of fish suggested by $\mathrm{FAO} / \mathrm{WHO}$ (7). According to literature, our data are in the limits reported by various authors $-1.1 \div 1.7 \mathrm{mg} / \mathrm{g}$ for muscle tissues in Cyprinus carpio from Yeşilirmak River in Tokat, Turkey (10); from $3.08 \mu \mathrm{g} / \mathrm{g}$ dry weight (for muscle), $10.03 \mu \mathrm{g} / \mathrm{g}$ dry weight (for gonads) and $15.13 \mu \mathrm{g} / \mathrm{g}$ dry weight (for liver) for Cyprinus carpio from Lake Pamvotis, Greece (12); 1.2-1.4 $\mu \mathrm{g} / \mathrm{g}$ for Cyprinus carpio from Bedrikale Lake, Turkey and 1.3-2.8 $\mu \mathrm{g} / \mathrm{g}$ for the same fish species from Avara Lake, Tokat, Turkey (9).

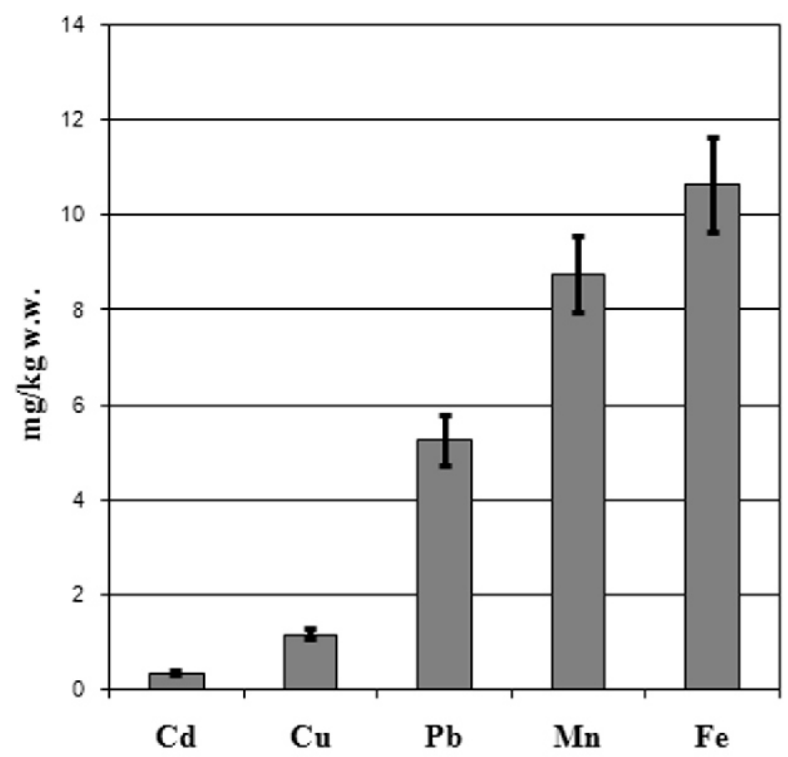

Fig.2. The mean heavy metal concentration in skin of cultured carp (Cyprinus carpio)

Lead is non-essential, a toxic element that can affects humans when ingested or inhaled in high doses (19). In fish, it can cause deficits or decrease in survival, growth rates, development and metabolism, in addition to increased mucus formation (4). The concentration of lead in our study varies from $0.45 \mu \mathrm{g}$ metal $/ \mathrm{g}$ w.w. (for liver) to $5.26 \mu \mathrm{g}$ metal $/ \mathrm{g}$ w.w. (for skin). The FAO/WHO has set a limit for heavy metal intake based on body weight (7). For an average adult (60 kg body weight), the provisional tolerable daily intake (PTDI) for lead was $214 \mathrm{mg}(8)$. The results for edible part of the fish are higher than the limits set of European Union
(6) and Bulgarian Food Codex (0.4 mg/kg f.w.) (3). According to the present results, the skin accumulated more lead than the liver and muscle tissues. Yilmaz et al. (2010) consider that the reason for high metal concentrations in the skins should be metal completing with mucus that is impossible to remove completely from the tissues before the analysis (19). It has been reported by Alam et al (2002) that the concentration of $\mathrm{Pb}$ in the liver of cultured carp caught in Lake Kasumigaura is $0.0904 \mathrm{mg} / \mathrm{kg}$, in intestine - 0.0459 $\mathrm{mg} / \mathrm{kg}$ and in gonads $-0.0290 \mathrm{mg} / \mathrm{kg}$ (1). In lake Beyşeir, Turkey $C$. Carpio had shown a concentration of $\mathrm{Pb}$ in muscle as $0.303 \mu \mathrm{g} / \mathrm{g}$ (2) while Park and Presley have determined this trace metal level and the results varied from 1.95 to $4.76 \mu \mathrm{g} / \mathrm{g}$ (13). Our lead values are higher than other literature values.

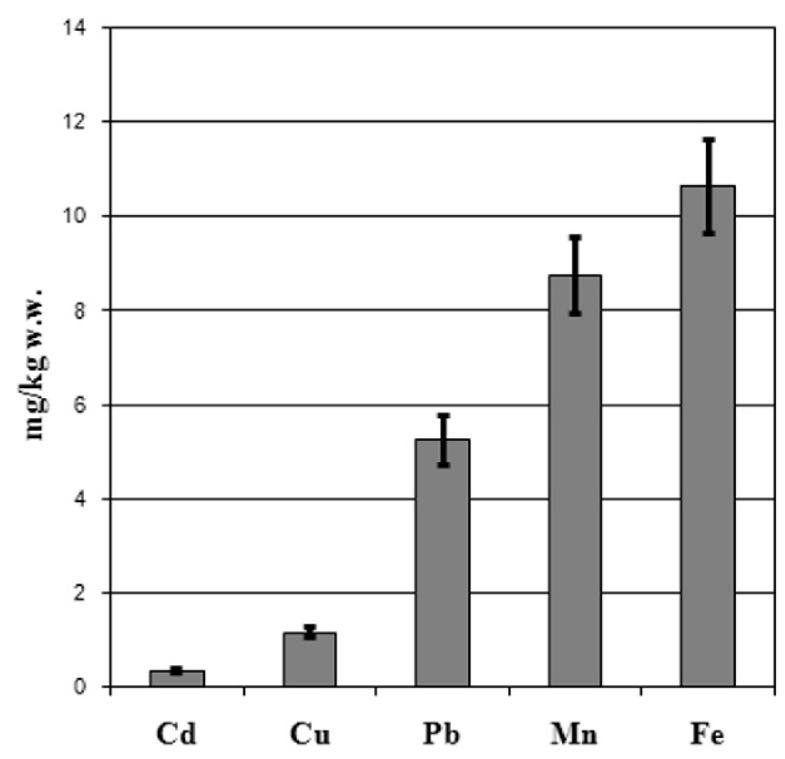

Fig.3. The mean heavy metal concentration in gills of cultured carp (Cyprinus carpio)

Manganese is essential trace element and its metabolitic role includes manganese containing enzyme systems. A deficiency of that essential element can lead to skeletal and reproductive abnormalities in mammals (15). Our results show maximum and minimum level of $\mathrm{Mn}$ in skin $(8.74 \mathrm{mg} / \mathrm{kg}$ w.w.) and liver ( $0.05 \mathrm{mg} / \mathrm{kg}$ w.w.), respectively. Manganese has been reported in the range of $9.6-64.3 \mu \mathrm{g} / \mathrm{g}$ in muscle tissues of Cyprinus carpio in Lake Tokat, Turkey (9); 1.04 to $8.77 \mu \mathrm{g} / \mathrm{g}$ w.w. in muscle tissues of different fish species from Iskenderun Bay, Turkey (19); and $0.3599 \mathrm{mg} / \mathrm{kg}$ for liver, $1.5256 \mathrm{mg} / \mathrm{kg}$ for intestine, 0.1766 for muscle of cultured crab from Lake Kasumigaura (1). Totally daily intake varies from 2.5 to $7 \mathrm{mg}$ for humans (11). Manganese contents in the analyzed samples (especially the one for muscle tissues) are smaller than reported by literature.

Average iron concentration of the fish sample varied from $9.02 \mathrm{mg} / \mathrm{kg} \mathrm{w}$.w. for bones to $55.54 \mathrm{mg} / \mathrm{kg}$ w.w. for gills. These values are in the range measured in some edible fish species by other authors. Mendil \& Uluözlü (2007) (9) obtained Fe concentrations between 88.8-158 $\mu \mathrm{g} / \mathrm{g}$ in muscle 


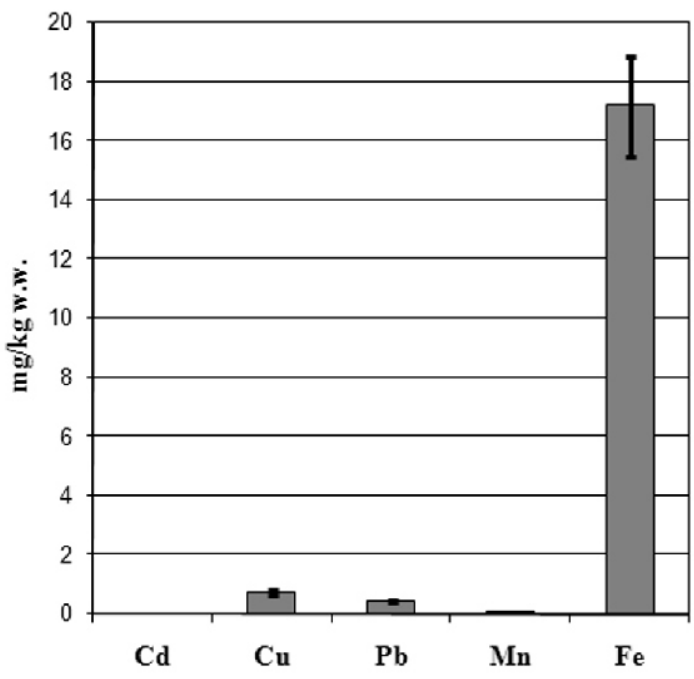

Fig.4. The mean heavy metal concentration in liver of cultured carp (Cyprinus carpio)

tissues of Cyprinus carpio in six different lakes in Turkey; between 14.4 and $37.2 \mu \mathrm{g} / \mathrm{g}$ in muscle tissues of cultured crap in Yeşilirmak River in Tokat, Turkey (19) and from $4.12 \mathrm{mg} / \mathrm{kg}$ (muscle) up to $179 \mathrm{mg} / \mathrm{kg}$ (liver) for cultured Lake Kasimiguara crap (1). This discrepancy might be because iron content depends on species, individuals, and sampling period.

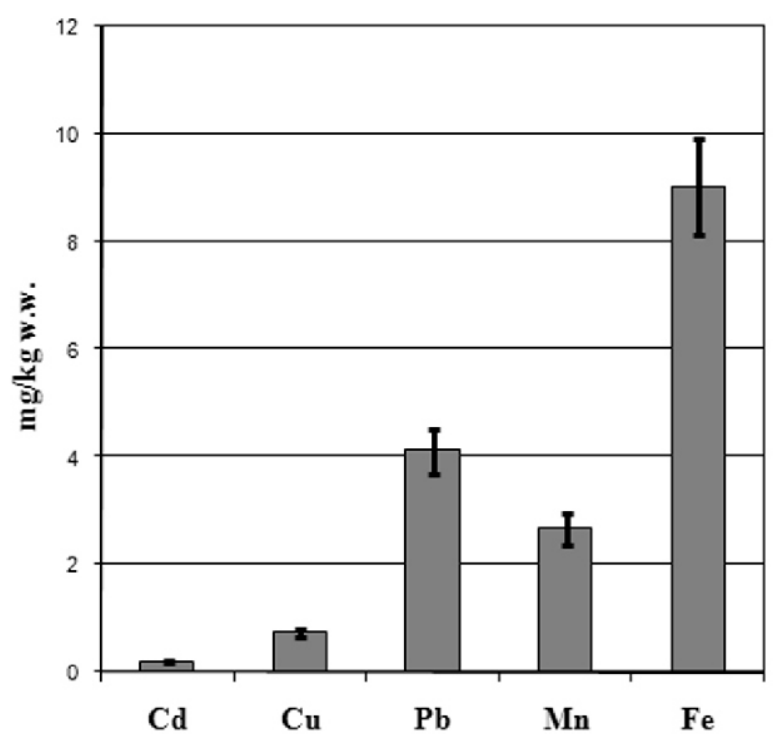

Fig.5. The mean heavy metal concentration in bones of cultured carp (Cyprinus carpio)

\section{CONCLUSIONS}

Iron present the highest concentrations followed by $\mathrm{Mn}$, $\mathrm{Pb}, \mathrm{Cu}$ and $\mathrm{Cd}$. The highest concentrations of the analyzed elements were found in skin, gills and bones while the lowest concentrations of detected metals were in muscle and liver. The last statement is a controversial to all the data stated in the literature. Many studies showed that heavy metals accumulate mainly in metabolic organs such as liver that stores metals to detoxificate by producing metallothioneins.

In the present study, the concentration of $\mathrm{Pb}$ in all tissues of carp collected from Tzonevo dam were higher than those stated by various health organizations the data reported in the literature. Thus they may affect or alter the ecosystem structure and food webs of the lake. In Tzonevo Dam, the concentrations of heavy metals in fish where high, possibly due to contamination of the water by metals or the geochemical structure of the region.

\section{ACKNOWLEDGMENTS}

The authors would like to thank the National Science Fund, Ministry of Education and Science of Bulgaria for their financial support (Project DVU 440 / 2008).

\section{REFERENCES}

1. Alam, M.G.M., Tanaka, A., Allinson, G. L., Laurenson, J.B., Stagnitti, F., \& Snow, F. (2002) A comparison of trace element concentrations in cultured and wild carp (Cyprinus carpio) of Lake Kasumigaura, Japan. Ecotoxicology and Environmental Safety 53, 348-354

2. Altinda $\breve{g}$, A., Yiğit, S. (2005) Assessment of heavy metal concentrations in the food web of lake Beyşehir, Turkey, Chemiosphere 60, 552-556

3. Anonymous (2004), Naredba № 31, Darjaven vestnik 88/2004 .

4. Burger, J., Gaines, K. F., Boring, C. S., Stephens, W. L., Snodgrass, J., Dixon, C., (2002) Metal levels in fish from the Savannah River: Potential hazards to fish and other receptors, Environmental Research A 89, 85-97

5. Dural, M., Göksu M.Z.L., Özak A.A., (2007) Investigation of heavy metal levels in economically important fish species captured from the Tuzla lagoon, Food Chemistry 102, 415-421

6. EU Commission Regulation as regards heavy metals. Directive 2001/ 22/ EC, No. 466/2001 EEC as amended by regulation 221/2002/ EC

7. FAO/WHO Expert Committee on Food Additives, Cadmium; http:/www.inchem.org /documents/ jecfa/ jeceval/jec_297.htm, 2005

8. Joint FAO/WHO (1999). Expert Committie on Food Additives. Summary and Conclusions, 53rd Meeting, Rome, 1-10 June.

9. Mendil, D., Uluözlü, Ö. D. (2007) Determination of trace metal levels in sediments and five fish species from lakes in Tokat, Turkey, Food Chemistry 101, 739-745

10. Mendil, D., Ünal, Ö. F., Tüzen, M., Soylak, M. (2010) Determination of trace metals in different fish species and sediments from the River Ye?il?rmak in Tokat, Turkey, Food and Chemical Toxicology 48, 1383-1392

11. NAS-NRC (1982) National Academy of Sciences. National Research Council. Drinking Water and 
Health (vol.4). Washington DC: National Academic Press, 299.

12. Papagiannis, I., Kagalou, I., Leonardos, J., Petridis, J., Kalfakakou, V. (2004) Copper and zinc in four freshwater fish species from Lake Pamvotis (Greece), Environmental International 30, 357-362

13. Park, J., Presley, B.J., (1997). Trace metal contamination of sediments and organism from the swan lake area of Galveston bay, Environmental Pollution, 98, 209-221

14. Rashed, M. N. (2001). Monitoring of environmental heavy metals in fish from Nasser Lake. Environmental International 27, 27-33.

15. Sivaperumal, P., Sankar, T.V., \& Viswanathan Nair, P. G. (2007) Heavy metal concentrations in fish, shellfish and fish products from internal markets of India vis-á-vis international standards, Food Chemistry 102, 612-620
16. Tariq, J., Jaffar, M., \& Moazzam, M., (1991). Concentration correlations between major cations and heavy metals in fish from the Arabian Sea, Marine Pollution Bulletin 22(11), 562-565.

17. Tuzen, M. (2003) Determination of heavy metals in fish samples of the middle Black Sea (Turkey) by graphite furnace atomic absorption spectrometry, Food Chemistry 80, 119-123

18. Uysal, K., Emre, Y., Köse, E. (2008) The determination of heavy metal accumulation ratios in muscle, skin and gills of some migratory fish species by inductively coupled plasma-optical emission spectrometry (ICP-OES) in Beymelek Lagoon (Antalya/Turkey), Microchemical Journal 90, 67-70

19. Yilmaz, A.B., Sangün, M. K., Yağlioğlu, D., Turan, C. (2010) Metals (major, essential to non-essentials) composition of the different tissues of three demersal fish species from Iskenderun Bay, Turkey, Food Chemistry 123, 410-415 